\title{
$N$-Vinyl- and $C$-Vinylpyrroles from Azafulvenium Methides. Flash Vacuum Pyrolysis Route to 5-Oxo-5H-pyrrolizines and 1-Azabenzo[f]azulenes
}

\author{
Teresa M. V. D. Pinho e Melo, ${ }^{* \dagger}$ Maria I. L. Soares ${ }^{\dagger}{ }^{\text {António M. d’A. Rocha Gonsalves, }}{ }^{\dagger}$
}

José A. Paixão,

Departamento de Química, Universidade de Coimbra, 3004-535 Coimbra, Portugal, and Departamento de Física, Universidade de Coimbra, 3004-516 Coimbra, Portugal

tmelo@ci.uc.pt

Received March 10, 2005

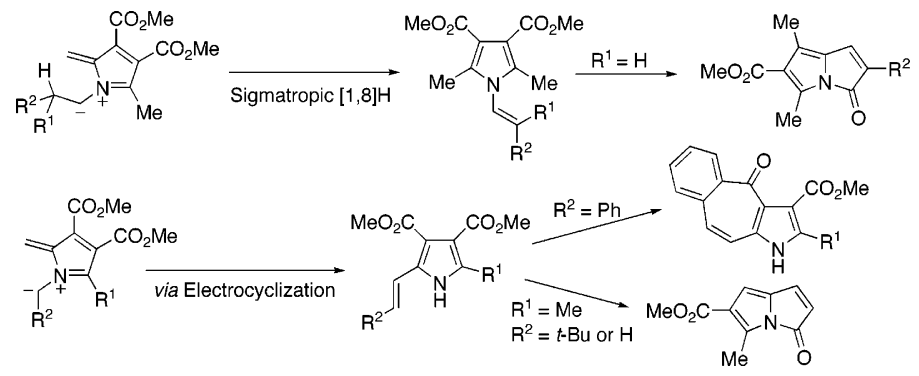

1-Azafulvenium methides, generated from pyrrolo[1,2-c]thiazole-2,2-dioxides' thermal extrusion of sulfur dioxide, led to the synthesis of functionalized pyrroles. The intramolecular trapping of these transient $8 \pi$ 1,7-dipoles in pericyclic reactions, namely sigmatropic $[1,8] \mathrm{H}$ shifts and 1,7electrocyclization, allowed the synthesis of $N$-vinylpyrroles and $C$-vinylpyrroles which, under flash vacuum pyrolysis conditions, are converted into 5-oxo-5H-pyrrolizines or 4-oxo-1,4-dihydro-1-azabenzo[f] azulenes, respectively. These heterocycles can also be obtained directly from FVP of pyrrolo$[1,2$-c $]$ thiazole 2,2 -dioxides. The synthesis and X-ray structure of a new 6-oxocyclopenta[b]pyrrole derivative is also reported.

\section{Introduction}

The generation of 1-azafulvenium methides $(\mathbf{1 a}-\mathbf{d})$ by the thermal extrusion of sulfur dioxide from pyrrolo[1,2c]thiazole-2,2-dioxides under flash vacuum pyrolysis (FVP) conditions has been reported. ${ }^{1}$ These extended dipolar systems 1a-c undergo sigmatropic $[1,8] \mathrm{H}$ shifts giving vinylpyrroles, and the acyl derivatives 1d electrocyclize to give pyrrolo[1,2-c][1,3] oxazines.

In relation with our ongoing research, ${ }^{2}$ we became interested in exploring the generation of azafulvenium methides in order to get further knowledge on the reactivity of these transient $8 \pi 1,7$-dipoles. In a preliminary communication, we have shown that 1 -azafulvenium methides (1), generated by the thermal extrusion of sulfur dioxide from pyrrolo[1,2-c]thiazole-2,2-dioxides $(\mathbf{2 a}, \mathbf{2 b}$, and $\mathbf{2 \mathbf { j }})$, are valuable intermediates for the

\footnotetext{
† Departamento de Química, Universidade de Coimbra.

¥ Departamento de Física, Universidade de Coimbra.

(1) (a) Sutcliffe, O. B.; Storr, R. C.; Gilchrist, T. L.; Rafferty, P.; Crew, A. P. A. Chem. Commun. 2000, 675-676. (b) Sutcliffe, O. B.; Storr, R. C.; Gilchrist, T. L.; Rafferty, P. J. Chem. Soc., Perkin Trans. 12001 1795-1806.
}

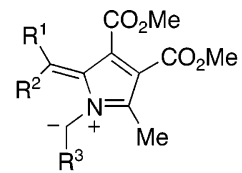

$$
\begin{aligned}
& \text { 1a } R^{1}=R^{2}=H ; R^{3}=C_{3} \\
& \text { 1b } R^{1}=H ; R^{2}=C_{3} ; R^{3}=H \\
& \text { 1c } R^{1}=R^{2}=C_{3} ; R^{3}=H \\
& \text { 1d } R^{1}=H ; R^{2}=C O R ; R^{3}=H
\end{aligned}
$$

synthesis of heterocylic compounds (Scheme 1). ${ }^{3}$ Sealed tube reaction conditions allow the synthesis of $N-(\mathbf{3 a})$

(2) (a) Pinho e Melo, T. M. V. D.; Barbosa, D. M.; Ramos, P. J. R. S.; Rocha Gonsalves, A. M. d’A.; Gilchrist, T. L.; Beja, A. M.; Paixão, J. A.; Silva, M. R.; Alte da Veiga, L. J. Chem. Soc., Perkin Trans. 11999 , 1219-1223. (b) Pinho e Melo, T. M. V. D.; Soares, M. I. L.; Barbosa, D. M.; Rocha Gonsalves, A. M. d'A.; Paixão, J. A.; Beja, A. M.; Silva, M. R.; Alte da Veiga, L. Tetrahedron 2000, 56, 3419-3424. (c) Pinho e Melo, T. M. V. D.; Soares, M. I. L.; Rocha Gonsalves, A. M. d'A.; Paixão, J. A.; Beja, A. M.; Silva, M. R.; Alte da Veiga, L.; Costa Pessoa, J. J. Org. Chem. 2002, 67, 4045-4054. (d) Pinho e Melo, T. M. V. D.; Gomes, C. S. B.; Rocha Gonsalves, A. M. d'A.; Paixão, J. A.; Beja, A. M.; Ramos Silva, M.; Alte da Veiga, L. Tetrahedron 2002, 58, 50935102.

(3) Pinho e Melo, T. M. V. D.; Soares, M. I. L.; Rocha Gonsalves, A. M. d'A.; McNab, H. Tetrahedron Lett. 2004, 45, 3889-3893. 


\section{SCHEME 1}

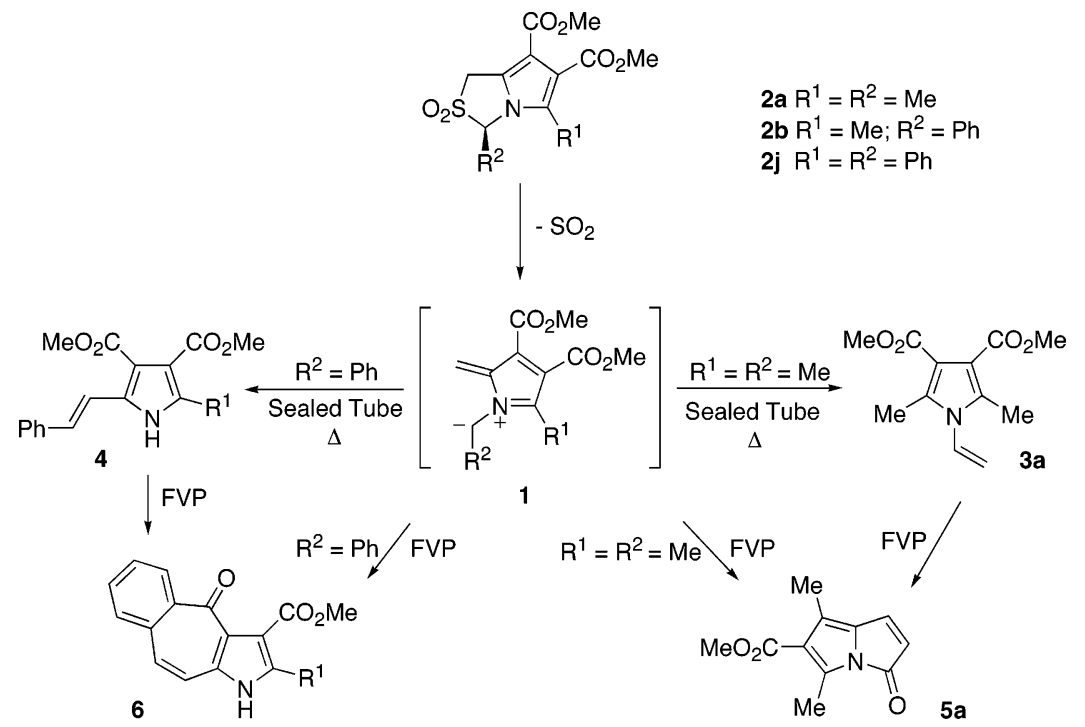

\section{SCHEME 2}

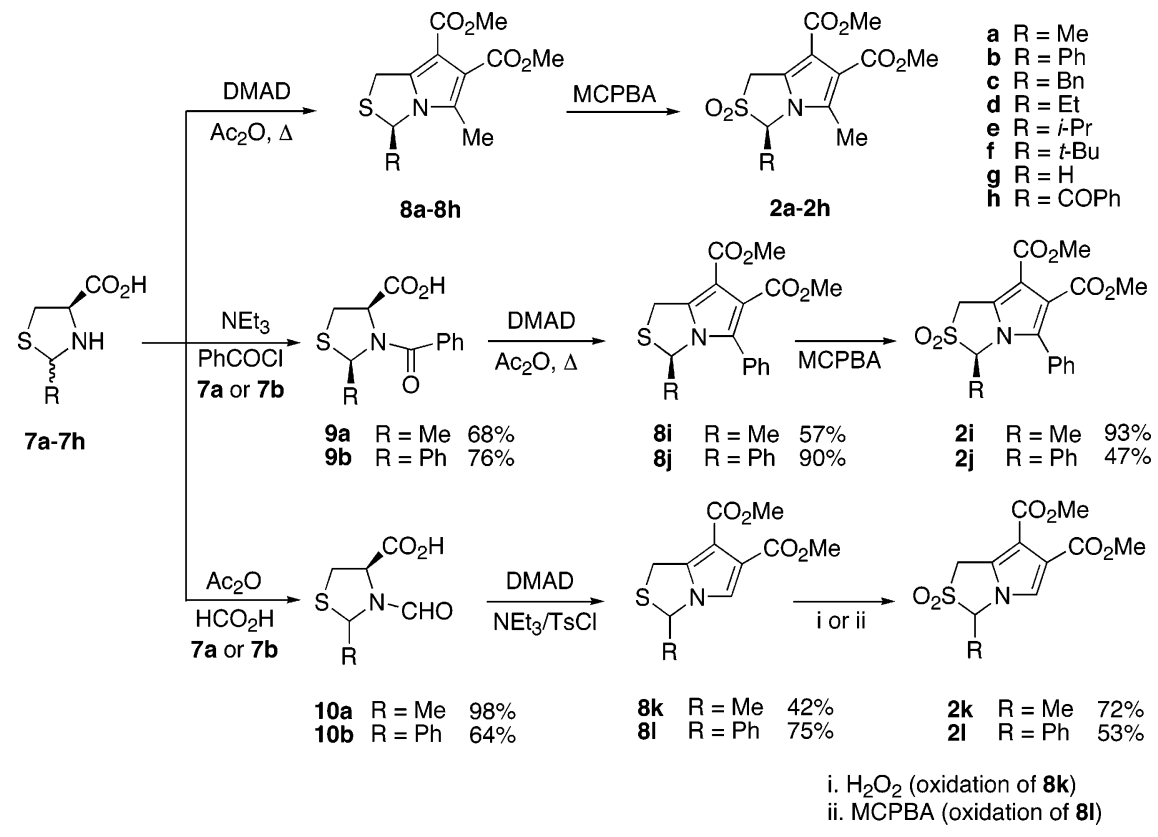

and $C$-vinylpyrroles (4) whereas FVP conditions lead to heterocycles where another ring system is annulated to pyrrole, namely 1,3-dimethyl-5-oxo-5 $\mathrm{H}$-pyrrolizine-2-carboxylate (5a) and 2-methyl-4-oxo-1,4-dihydro-1-azabenzo[f]azulene-3-carboxylate (6). It was demonstrated that $N$ (3a) and $C$-vinylpyrroles (4) were intermediates in the formation of 1,3-dimethyl-5-oxo-5 $H$-pyrrolizine-2-carboxylate (5a) and 2-methyl-4-oxo-1,4-dihydro-1-azabenzo[f]azulene-3-carboxylate (6), respectively, starting from the pyrrolo[1,2-c] thiazole 2,2-dioxides. Thus, the corresponding pyrrolo-annulated heterocycles were obtained by carrying out the FVP of $N$-vinylpyrrole $\mathbf{3 a}$ and the FVP of styryl-1H-pyrroles 4.

In this paper, we describe full details of an extensive study on the generation and reactivity of azafulvenium methides as well as the study of the thermolysis of $N$-vinyl- and $C$-vinylpyrroles.

\section{Results and Discussion}

The 5-methyl- $1 H$-pyrrolo[1,2-c]thiazole-2,2-dioxides $\mathbf{2 a}-\mathbf{h}$ were prepared from L-cysteine as outlined in Scheme 2 . Heating a solution of the thiazolidine $(\mathbf{7 a - 7 h})$ in acetic anhydride in the presence of dimethyl acetylenedicarboxylate, the corresponding 5-methylpyrrolo[1,2c] thiazoles $(\mathbf{8 a}-\mathbf{c}$ and $\mathbf{8 e}-\mathbf{h})$ were obtained in good yield (48-94\%). The 3-ethyl-5-methyl-1H-pyrrolo[1,2-c]thiazole $\mathbf{8 d}$ could only be obtained in low yield (9\%). An attempt was made to improve the synthesis of compound $\mathbf{8 d}$. The acylation of thiazolidine $\mathbf{7 d}$ was carried out with acetic anhydride to give the $N$-acyl derivative in $52 \%$ yield. When this $N$-acetyl-2-ethylthiazolidine was heated in acetic anhydride in the presence of dimethyl acetylenedicarboxylate, pyrrolo[1,2-c] thiazole 8d was again obtained in low yield (15\%). Oxidation of the heterocycles $\mathbf{8 a}-\mathbf{h}$ with $m$-CPBA gave sulfones $\mathbf{2 a}-\mathbf{h}$ with yields ranging from $33 \%$ to $94 \%$. In the oxidation of $\mathbf{8 f}$, the 


\section{SCHEME 3}
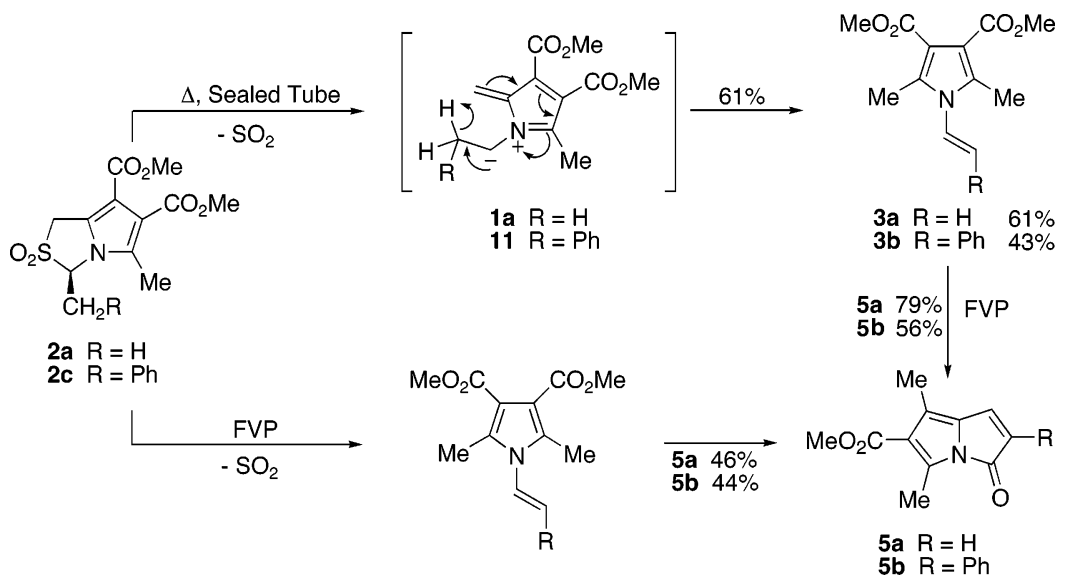

corresponding sulfoxide was also obtained in $8 \%$ yield. The synthesis of the pyrrolo[1,2-c]thiazole 2,2-dioxides bearing a phenyl at $\mathrm{C}-5(\mathbf{2} \mathbf{i}-\mathbf{j})$ required, as the first step, the $N$-acylation of the starting thiazolidine with benzoyl chloride following a general procedure previously reported. ${ }^{2 \mathrm{~d}}$ The cyclodehydration of the $N$-benzoylthiazolidines led to the generation of 5-phenyl-5H,7H-thiazolo[3,4-c]oxazol-4-ium-1-olates which participate in the 1,3-dipolar cycloaddition with dimethyl acetylenedicarboxylate to give pyrrolo[1,2-c] thiazoles $\mathbf{8 i}$ and $\mathbf{8 j}$, respectively. Sulfones $\mathbf{2 i}$ and $\mathbf{2 j}$ are obtained by oxidation with $m$-CPBA. Scheme 2 shows also the route used to prepare the pyrrolo[1,2-c] thiazole 2,2-dioxide derivatives unsubstituted at C-5. Formylation of thiazolidines $\mathbf{7 a}$ and $\mathbf{7 b}$ was carried out by reaction with formic acid and acetic anhydride following a known procedure. ${ }^{4}$ Treatment of the $N$-formylthiazolidines (10a and 10b) with triethylamine and tosyl chloride in the presence of dimethyl acetylenedicarboxylate afforded the pyrrolo[1,2-c]thiazoles 8k and 81. ${ }^{5}$ The oxidation of $\mathbf{8 k}$ with $m$-CPBA leads to the sulfone $\mathbf{2 k}$ in low yield (17\%) together with the formation of the corresponding sulfoxide in $11 \%$ yield. However, when hydrogen peroxide was used as the oxidant, sulfone $\mathbf{2 k}$ was obtained in $72 \%$ yield. The reaction of $\mathbf{8 1}$ with $m$-CPBA gave sulfone $\mathbf{2 1}$ as the major product $(53 \%)$ with the formation of the sulfoxide in $13 \%$ yield.

As a first objective we decided to look more carefully into the generation of azafulvenium methide $\mathbf{1 a}$ (Scheme $3)$. It has been reported that on $\operatorname{FVP}\left(700^{\circ} \mathrm{C} / 1.3 \times 10^{-3}\right.$ mbar) sulfone $\mathbf{2 a}$ leads to vinylpyrrole $\mathbf{3 a}$ via an allowed, suprafacial $[1,8] \mathrm{H}$ shift in the $8 \pi$ 1,7-dipolar system 1a. ${ }^{1}$ We found that the same vinylpyrrole $(\mathbf{3 a})$ could be obtained in $61 \%$ yield carrying out the reaction in a sealed tube allowing us to conclude that sulfone $\mathbf{2 a}$ extrudes sulfur dioxide without the need of FVP conditions.

The flash vacuum pyrolysis of sulfone $\mathbf{2 a}$ was also studied. Interestingly, our FVP conditions $\left(700{ }^{\circ} \mathrm{C} / 8 \times\right.$ $10^{-2}$ mbar) led to a different outcome than the previously reported result. ${ }^{1}$ One product was obtained in $46 \%$ yield

(4) Experimental procedure described for the formylation of 2-(pyridin-3-yl)-1,3-thiazolidine in: Fabre, J.-L.; Farge, D.; James, C.; Lavé, D. US Patent 4,529,728.

(5) Experimental procedure described for the synthesis of 7-cyano3-(3-pyridyl)-1H,3H-pyrrolo[1,2-c]thazole in: Rajoharison, H. G., US Patent 5,124,459. and identified as being methyl 1,3-dimethyl-5-oxo-5Hpyrrolizine-2-carboxylate 5a. ${ }^{3}$ When the FVP of $\mathbf{2 a}$ was carried out at $700{ }^{\circ} \mathrm{C} / 4 \times 10^{-2}$ mbar, a mixture of $\mathbf{5 a}$ $(44 \%)$ and $\mathbf{3 a}(27 \%)$ was obtained. This suggested that the lower pressure reduces the period of time that the substance to be pyrolyzed remains in the hot zone not allowing the complete conversion of $\mathbf{2 a}$ into compound 5a. The result of the sulfone $2 \mathbf{a} \operatorname{FVP}\left(700{ }^{\circ} \mathrm{C} / 1.3 \times 10^{-3}\right.$ mbar) described by Storr et al. ${ }^{1}$ is also in agreement with this observation. Thus, vinylpyrrole $\mathbf{3 a}$ must in fact be an intermediate in the formation of methyl 1,3-dimethyl5-oxo-5H-pyrrolizine-2-carboxylate $\mathbf{5 a}$ from sulfone $\mathbf{2 a}$. To corroborate this mechanistic interpretation, we performed the FVP of dimethyl 2,5-dimethyl-1-vinyl-1 $H$ pyrrole-3,4-dicarboxylate 3a. In fact, the flash vacuum pyrolysis carried out at $700{ }^{\circ} \mathrm{C} / 4 \times 10^{-2} \mathrm{mbar}$ led to the efficient synthesis of compound $\mathbf{5 a}(79 \%)$. The FVP of compound $\mathbf{3 a}$ was also performed using milder reaction conditions $\left(400{ }^{\circ} \mathrm{C}\right.$ and $550{ }^{\circ} \mathrm{C} / 4 \times 10^{-2} \mathrm{mbar}$ ) in an attempt to intercept intermediates of the synthesis of $\mathbf{5 a}$. However, only sublimation of $N$-vinylpyrrole $\mathbf{3 a}$ was observed.

We set out to evaluate the scope of the approach to $\mathrm{N}$-vinylpyrroles and 5-oxo-5 $\mathrm{H}$-pyrrolizines from pyrrolo[1,2-c] thiazole 2,2-dioxides.

The reactivity of 3-benzyl- $1 H$-pyrrolo[1,2-c] thiazole 2,2dioxide 2c was studied (Scheme 3). The thermolysis of 2c carried out in a sealed tube led to $N$-vinylpyrrole $\mathbf{3 b}$ in $43 \%$ yield. On the other hand, compound 2c was converted into 5-oxo-5H-pyrrolizine $\mathbf{5 b}$ on FVP (44\%). The same product was obtained from the FVP of $\mathbf{3 b}$ confirming that the $N$-vinylpyrrole $\mathbf{3 b}$ is an intermediate of the synthesis of 5-oxo-5H-pyrrolizine $\mathbf{5 b}$ from pyrrolo[1,2-c] thiazole 2c.

Starting from a pyrrolo[1,2-c]thiazole 2e bearing an isopropyl group at C-3, pyrrole 13a was obtained in moderate yield. The two substituents at the terminus of the double bond of $\mathbf{1 3 a}$ preclude its conversion into a pyrrolizine. ${ }^{3}$ Nevertheless, we hoped that this study would give new information concerning the reactivity of this type of pyrroles. Under FVP reaction conditions, two products were obtained, the $N$-vinylpyrrole $\mathbf{1 3 a}$ and 6 -oxocyclopenta $[b]$ pyrrole 14 . The 6 -oxocyclopenta[b]pyrrole 14 structure was determined by X-ray crystallography (see the Supporting Information). We could also conclude that the presence of a substituent ( $\mathrm{Me}$ or $\mathrm{Ph}$ ) 


\section{SCHEME 4}
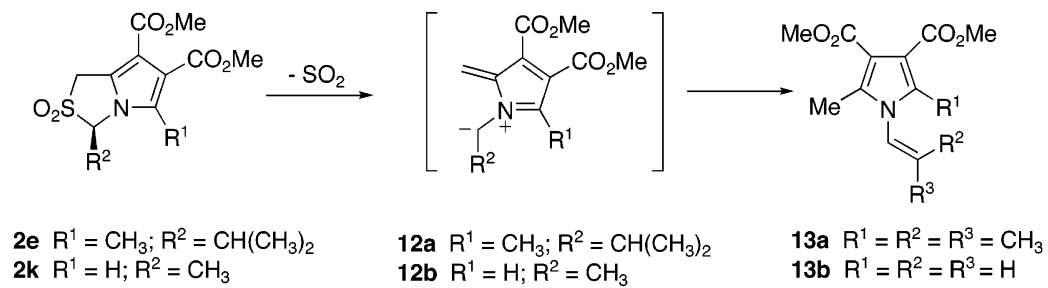

\begin{tabular}{|c|c|c|c|c|}
\hline & Starting Material & Reaction Conditions & Product & \\
\hline & $\begin{array}{l}2 e \\
2 e \\
2 k \\
2 k\end{array}$ & $\begin{array}{l}\Delta \text {, sealed tube } \\
\text { FVP } \\
\Delta \text {, sealed tube } \\
\text { FVP }\end{array}$ & $\begin{array}{l}\text { 13a }(36 \%) \\
13 a(13 \%) \\
13 b(8 \%) \\
13 b(11 \%)\end{array}$ & $14(7 \%)$ \\
\hline
\end{tabular}

TABLE 1.

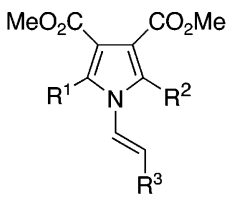

15a $R^{1}=R^{2}=R^{3}=M e$

15b $R^{1}=P h ; R^{2}=M e ; R^{3}=H$

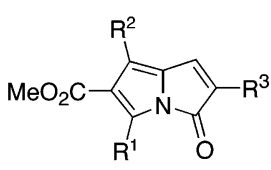

16a $R^{1}=R^{2}=R^{3}=M e$

16b $R^{1}=P h ; R^{2}=M e ; R^{3}=H$

16c $R^{1}=M e ; R^{2}=P h ; R^{3}=H$

\begin{tabular}{lllll}
\hline $\begin{array}{c}\text { starting } \\
\text { material }\end{array}$ & $\begin{array}{c}\text { reaction } \\
\text { conditions }\end{array}$ & \multicolumn{1}{c}{ products } & \\
\hline $\mathbf{2 d}$ & sealed tube & $\mathbf{1 6 a}(7 \%)$ & & $\mathbf{1 5 a}(41 \%)$ \\
$\mathbf{2 d}$ & FVP & $\mathbf{1 6 a}(39 \%)$ & & \\
$\mathbf{1 5 a}$ & FVP & $\mathbf{1 6 a}(72 \%)$ & & $\mathbf{1 5 b}(45 \%)$ \\
$\mathbf{2 i}$ & sealed tube & & & $\mathbf{1 5 b}(3 \%)$ \\
$\mathbf{2 i}$ & FVP & $\mathbf{1 6 b}(8 \%)$ & $\mathbf{1 6 c}(13 \%)$ & $\mathbf{1 5 b}(3 \%)$ \\
$\mathbf{1 5 b}$ & FVP & $\mathbf{1 6 b}(8 \%)$ & $\mathbf{1 6 c}(10 \%)$ & $\mathbf{1 5 b}$ \\
\hline
\end{tabular}

at C-5 of the starting pyrrolo[1,2-c]thiazole is important in order to have an efficient process. In fact, the thermolysis of the unsubstituted derivative $2 \mathbf{k}$ led to $N$ vinylpyrrole $\mathbf{1 3 b}$ in poor yield (Scheme 4).

The synthesis of $N$-vinylpyrrole $\mathbf{1 5 a}$ and 5-oxo-5Hpyrrolizine 16a could also be achieved starting from pyrrolo[1,2-c] thiazole $\mathbf{2 d}$. When the reaction was carried out in a sealed tube $\left(260{ }^{\circ} \mathrm{C}, 1.5 \mathrm{~h}\right)$, a mixture of $\mathbf{1 5 a}$ $(41 \%)$ and 16a (7\%) was obtained. The FVP $\left(700{ }^{\circ} \mathrm{C}, 6 \times\right.$ $10^{-2}$ mbar) of $\mathbf{2 d}$ allowed the synthesis of pyrrolizine $\mathbf{1 6 a}$ in $39 \%$ yield. The same compound was obtained in $72 \%$ yield from 15a through FVP (Table 1).

In the case of pyrrolo[1,2-c] thiazole-2,2-dioxides $\mathbf{2 i}$, the sealed tube thermolysis leads to the expected $N$-vinylpyrrole 15b. However, from the FVP of $2 \mathbf{i}$ two isomeric 5-oxo$5 H$-pyrrolizines (16b and $\mathbf{1 6 c}$ ) were obtained together with the formation of some $N$-vinylpyrrole $\mathbf{1 5 b}$. The same compounds were obtained from the flash vacuum pyrolysis of $N$-vinylpyrrole $\mathbf{1 5 b}$ (Table 1 ). Based on a comparison of the ${ }^{1} \mathrm{H}$ NMR spectra of 5-oxo-5H-pyrrolizines $\mathbf{5 a}$, $\mathbf{5 b}, \mathbf{1 6 a}$, and 35 with those of derivatives $16 \mathrm{~b}$ and $\mathbf{1 6 c}$, we could determine the structures of these last compounds. Protons of methyl groups at the C-1 position of 5-oxo-5H-pyrrolizines are characterized by having resonances at lower chemical shift then the ones observed for methyl groups at C-3.

The mechanism of conversion of pyrrolo[1,2-c]thiazole 2,2-dioxides into $N$-vinylpyrroles was proposed by Storr et al., who first reported the synthesis of $N$-vinylpyrrole 3a from the 1-azafulvenium methide $\mathbf{1 a} .{ }^{1}$ It is an allowed, suprafacial $[1,8] \mathrm{H}$ shift in the $8 \pi$ 1,7-dipolar system (Scheme 3).

The formation of 5-oxo-5H-pyrrolizines from $\mathrm{N}$-vinylpyrroles can be rationalized as outlined in Scheme $5 .^{3}$ It is known that 2-substituted 3-(pyrrol-2-yl)propionate methyl esters undergo concerted elimination of methanol on FVP to give pyrrol-2-ylideneketene intermediates which give pyrrolizinones by electrocyclization. ${ }^{6}$ Thus, pyrrol-2-ylpropionates $\mathbf{1 7}$ must be intermediates in the synthesis of the 5-oxo-5H-pyrrolizines, formed from the $N$-vinylpyrroles through a sequence of sigmatropic shifts. The pyrrol-2-ylpropionates undergo concerted elimination of methanol giving pyrrol-2-ylideneketenes which are converted into pyrrolizinones by electrocyclization. The formation of 5-oxo-5H-pyrrolizines $\mathbf{1 6 b}$ and $\mathbf{1 6} \mathbf{c}$ followed the general mechanism outlined in Scheme 5. However, the synthesis of $\mathbf{1 6 b}$ involves a methyl migration as the second mechanistic step whereas in the case of 5-oxo$5 H$-pyrrolizine $\mathbf{1 6 c}$ it is a phenyl migration.

$N$-Vinylpyrrole $\mathbf{1 3 a}$ cannot be converted into a pyrrolizine of the type described in Scheme 5. Instead, this compound is converted into 6-oxo-cyclopenta[b]pyrrole $\mathbf{1 4}$ via an alternative mechanistic pathway outlined in Scheme 6.

The thermolysis of 3-phenyl- $1 H$-pyrrolo[1,2-c]thiazole2,2-dioxides $\mathbf{2 b}$ and $\mathbf{2 j}$ was also studied (Scheme 7 ). We found that the cheletropic extrusion of $\mathrm{SO}_{2}$ from these sulfones could be carried out in a sealed tube leading to styryl-1H-pyrroles (4a and $\mathbf{4 b}$ ). The best results were obtained by heating at $220{ }^{\circ} \mathrm{C}$ for $1.5 \mathrm{~h}$ a solution of $\mathbf{2 j}$ in sulfolane giving $\mathbf{4 b}$ in $80 \%$ yield. A similar result was obtained starting from 5 -methyl-3-phenyl- $1 H$-pyrrolo[1,2c] thiazole-2,2-dioxide $\mathbf{2 b}$, and the corresponding styryl$1 H$-pyrrole 4 a could be obtained in $54 \%$ yield. Storr et al. ${ }^{1 \mathrm{~b}}$ have described attempts of thermal extrusion of $\mathrm{SO}_{2}$ from $\mathbf{2 b}$ although no products of this reaction were reported.

The formation of styryl- $1 H$-pyrroles $\mathbf{4 a}$ and $\mathbf{4 b}$ can be explained considering the generation of azafulvenium methides (1e or 1f) followed by an 1,7-electrocyclic reaction giving $\mathbf{2 6 a}$ and $\mathbf{2 6 b}$, respectively, which rearrange to the final products. Attempts were made to trap 1f by promoting the sealed tube thermolysis in the

(6) (a) McNab, H. J. Chem. Soc., Perkin Trans. 1 1987, 657-659. (b) McNab, H.; Parson, S.; Stevenson, E. J. Chem. Soc., Perkin Trans. 1 1999, 2047-2048. (c) McNab, H. Aldrichim. Acta 2004, 37, 19-26. (d) Trofimov, B. A.; Sobenina, L. N.; Demenev, A. P.; Mikhaleva, A. I. Chem. Rev. 2004, 104, 2481-2506. 


\section{SCHEME 5}
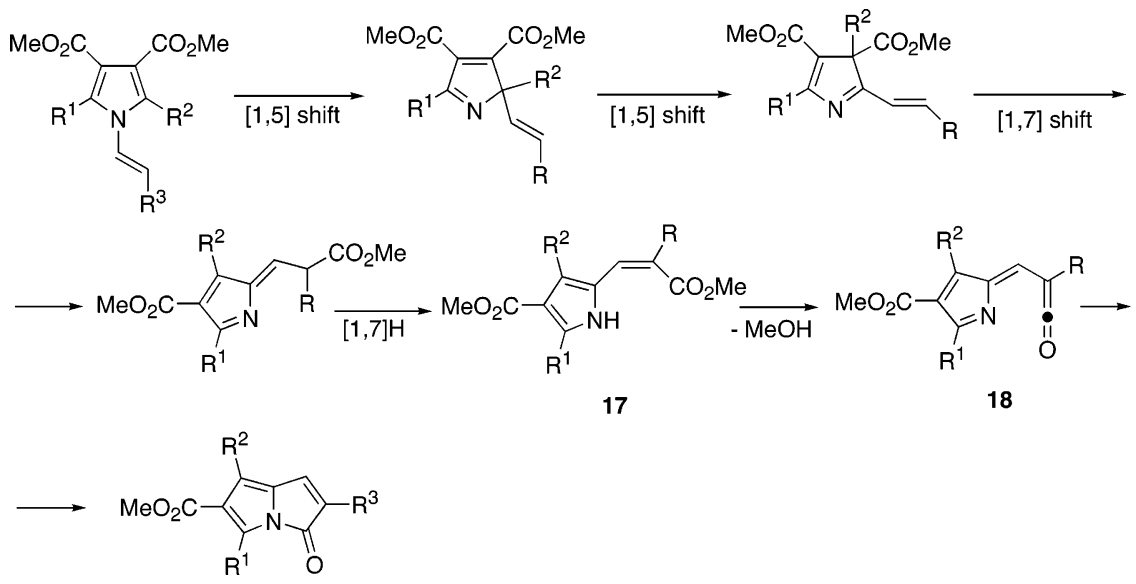

\section{SCHEME 6}
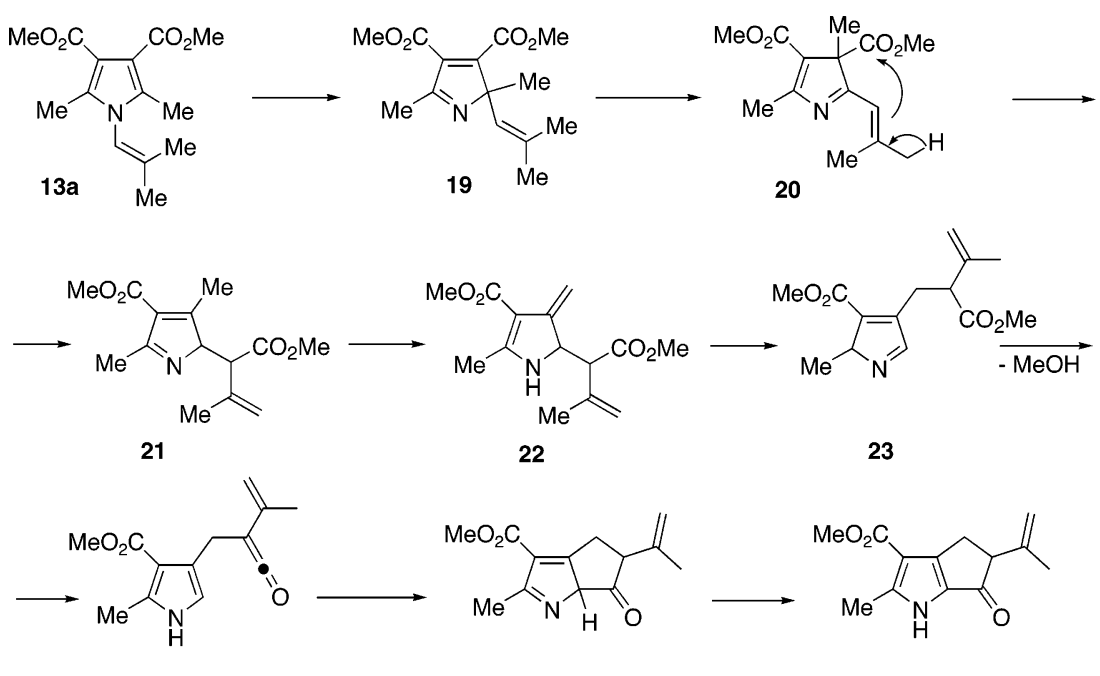

24

25

14

\section{SCHEME 7}

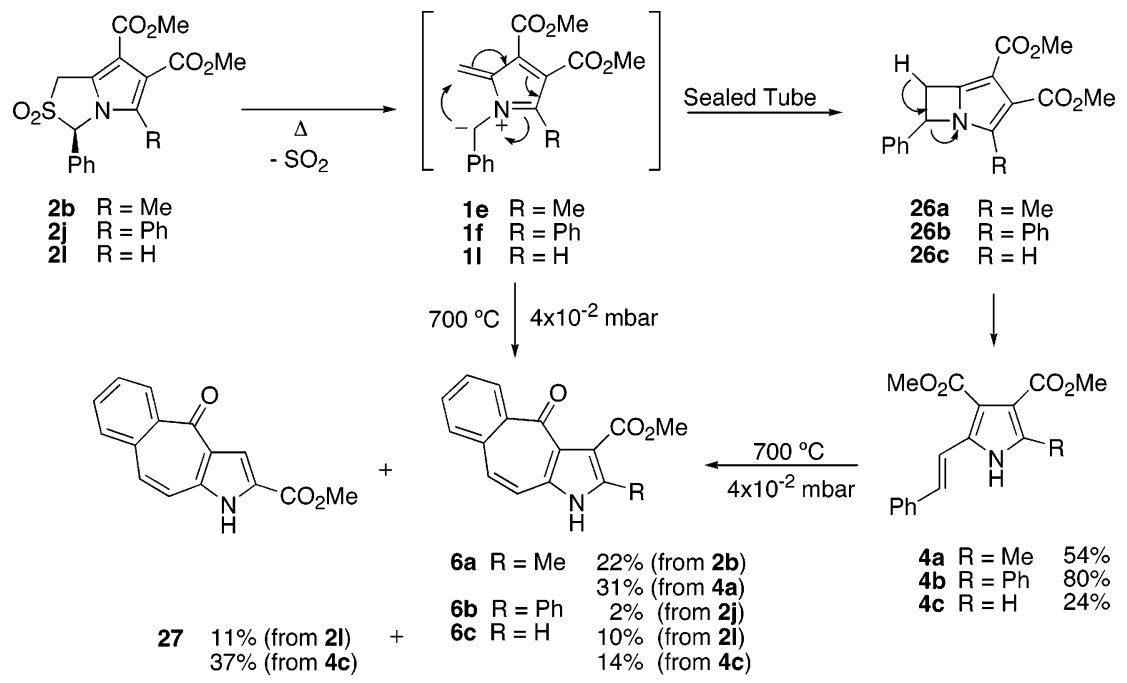

presence of DMAD and also in the presence of bis(trimethylsilyl)acetylene although no evidence was obtained for the formation of adducts and the only product was styryl- $1 H$-pyrrole $\mathbf{4 b}$. Nevertheless, the synthesis of pyrroles $4 \mathbf{a}$ and $\mathbf{4 b}$ is a strong evidence of the generation of the new azafulvenium methides $\mathbf{1 e}$ and $\mathbf{1 f}$.
5-Methyl-3-phenyl-1H-pyrrolo[1,2-c] thiazole 2,2-dioxide $\mathbf{2 b}$ is converted into methyl 2-methyl-4-oxo-1,4dihydro-1-azabenzo[f]azulene-3-carboxylate $\mathbf{6 a}$ on flash vacuum pyrolysis (Scheme 7). Under these reaction conditions, styryl- $1 H$-pyrrole $\mathbf{4 a}$ is formed and converted into a pyrrole fused to a benzocyclohepten-5-one ring 


\section{SCHEME 8}

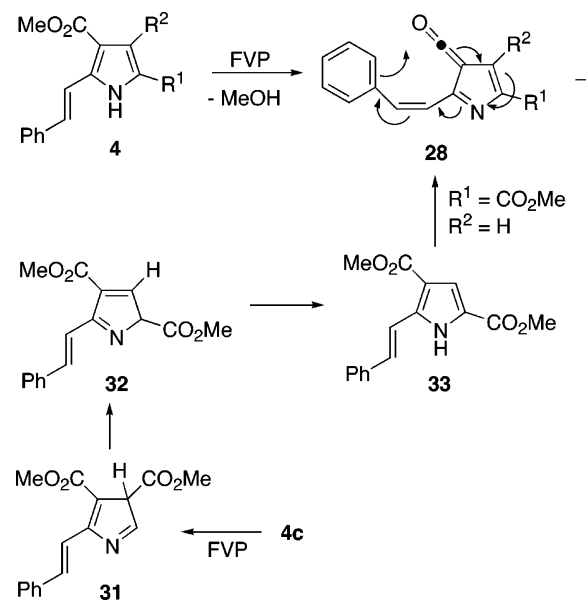

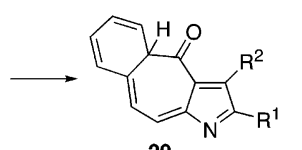

29 $\downarrow[1,5] \mathrm{H}$
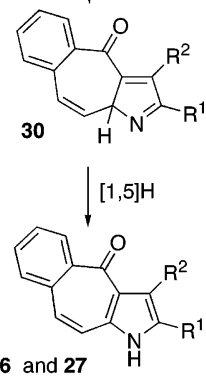

system. This was confirmed by promoting the FVP of styryl- $1 H$-pyrrole $\mathbf{4 a}$, which also gave compound $\mathbf{6 a}$ (31\%). 3-Phenyl-1H-pyrrolo[1,2-c] thiazole 2,2-dioxide 2j and styryl- $1 H$-pyrrole $\mathbf{4 b}$ showed similar chemical behavior when compared with $\mathbf{2 b}$ and $\mathbf{4 a}$, respectively, and the corresponding 4-oxo-1,4-dihydro-1-aza-benzo[f]azulene-3-carboxylate $\mathbf{6 b}$ could be obtained on FVP although in low yield.

The reactivity of 3 -phenyl- $1 H$-pyrrolo[1,2-c]thiazole 2,2-dioxide unsubstituted at C-5 (2l) toward thermolysis was also studied (Scheme 7). Sealed tube reaction conditions allowed the conversion of $\mathbf{2 l}$ into $C$-vinylpyrrole $\mathbf{4 c}$ in $24 \%$ yield. Interestingly, starting from sulfone 21 or from $C$-vinylpyrrole 4c the FVP results in the synthesis of two isomeric 4-oxo-1,4-dihydro-1-azabenzo[f]azulenes 6c and 27.

The most likely mechanism for the formation of $\mathbf{6}$ is shown in Scheme 8. It has been reported that methyl pyrrole-2-carboxylate undergoes elimination of methanol to produce pyrrol-2-ylketene under FVP conditions. ${ }^{7}$ In a similar manner, styryl- $1 H$-pyrrole 4 generates pyrrol3-ylketene $\mathbf{2 8}$ on eliminating methanol. Electrocyclization of 28 followed by two sigmatropic H-shifts gives compounds 6.

Since 4-oxo-1,4-dihydro-1-azabenzo[f]azulene 27 can be obtained from $C$-vinylpyrrole $4 \mathbf{c}$, the rationalization of its formation can also be done considering the initial isomerization of $\mathbf{4 c}$ into $\mathbf{3 1}$ as outlined in Scheme 8. We assume that the existence of unsubstituted position in 4c favors the rearrangement in comparison with 2 -substituted pyrrole derivatives $\mathbf{4 a}$ and $\mathbf{4 b}$. Pyrrole 33 generates the corresponding pyrrol-3-ylketene on eliminating methanol, and this intermediate can lead to the final product $\mathbf{2 7}$.

Padwa et al. reported unsuccessful attempts to extrude sulfur dioxide from pyrrolo[1,2-c] thiazole 2,2-dioxide $\mathbf{2 g}$ by solution-phase thermolysis $\left(300{ }^{\circ} \mathrm{C}\right) .{ }^{8}$ Storr et al., considering that this unsuccessful result was due to the high thermal stability of this sulfone, characterized by the low bond order of the 3,4-bond of the sulfolene moiety,

(7) Gross, G.; Wentrup, C. J. Chem. Soc., Perkin Trans. 1 1982, 360361.

(8) Padwa, A.; Fryxell, G. E.; Gasdaska, J. R.; Venkatramanan, M. K.; Wong, G. S. K. J. Org. Chem. 1989, 54, 644-652.

\section{SCHEME 9}

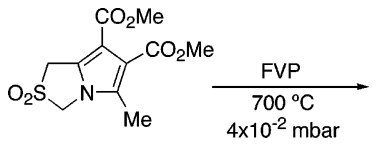

$2 g$
$3410 \%$

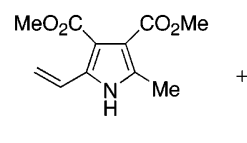

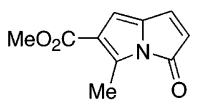

$358 \%$ attempted the flash vacuum pyrolysis $\left(700{ }^{\circ} \mathrm{C} / 1.3 \times\right.$ $10^{-3}$ mbar). ${ }^{1}$ Although sulfur dioxide was eliminated from sulfone $\mathbf{2} \mathbf{g}$ no identifiable products were detected.

We decided to evaluate if our FVP reaction conditions $\left(700{ }^{\circ} \mathrm{C} / 4 \times 10^{-2} \mathrm{mbar}\right)$ applied to the thermolysis of $\mathbf{2 g}$ would lead to a different outcome. In fact, under these conditions, two products are obtained from pyrrolo[1,2c] thiazole 2,2-dioxide $\mathbf{2 g}$, the $C$-vinylpyrrole $\mathbf{3 4}$ and 5-oxo$5 H$-pyrrolizine 35 , although in low yield. No product could be isolated from the sealed tube thermolysis of $\mathbf{2} \mathbf{g}$ (Scheme 9).

Evidence for the formation of 1-azafulvenium methide 36, the intermediate involved in the synthesis of $C$ vinylpyrrole 34, was observed for the first time (Scheme 10). This $8 \pi$ 1,7-dipolar system (36) does not have a proton in the appropriate position to allow the suprafacial $[1,8] \mathrm{H}$ shift of the type described in Scheme 3 for the synthesis of $N$-vinylpyrroles. Therefore, the process occurs via an alternative route; an 1,7-electrocyclic reaction gives 37 which undergoes a rearrangement to pyrrole 34 . This is in fact, a mechanism pathway similar to the one described for the phenyl derivatives 1e, 1f, and $\mathbf{1 1}$.

The mechanistic interpretation for the synthesis of 5-oxo-5H-pyrrolizine $\mathbf{3 5}$ from $\mathbf{3 4}$ is outlined in Scheme 10. We could conclude that $C$-vinylpyrroles can also be converted into the corresponding 5-oxo-5H-pyrrolizines.

We looked also into the thermolysis of $1 H$-pyrrolo[1,2c] thiazole 2,2-dioxide $2 \mathbf{f}$ (Scheme 11). The FVP $\left(700{ }^{\circ} \mathrm{C}\right.$, $4 \times 10^{-2}$ mbar) of this sulfone led to an unexpected result: 5-oxo-5H-pyrrolizine $\mathbf{3 5}$ was isolated in $24 \%$ yield, the same compound previously obtained from the FVP of $\mathbf{2 g}$. When the FVP was carried out at $700{ }^{\circ} \mathrm{C} / 6 \times 10^{-2}$ mbar two products were isolated, 5-oxo- $5 H$-pyrrolizine 35 and dimethyl 2-(3,3-dimethylbut-1-enyl)-5-methyl-1Hpyrrole-3,4-dicarboxylate 42. This result indicates this pyrrole is an intermediate in the synthesis of 5-oxo-5 $\mathrm{H}$ pyrrolizine 35. No product could be isolated from the sealed tube thermolysis of $\mathbf{2 f}$.

We could conclude that $1 H$-pyrrolo[1,2-c] thiazole 2,2dioxide $2 \mathbf{f}$ shows a similar chemical behavior to the one described for sulfone $\mathbf{2 g}$ giving a $C$-vinylpyrrole. The synthesis of $\mathbf{3 5}$ from $\mathbf{4 2}$ can be explained considering an initial rearrangement followed by isobutene elimination to give 3-(pyrrol-2-yl)propionate 40, which is converted into the final product (Scheme 12).

Storr et al. reported that azafulvenium methides $\mathbf{1 d}$ electrocyclize to give pyrrolooxazines. ${ }^{1}$ Attempts were made to generate azafulvenium methide $\mathbf{4 4}$ in order to explore the same type of chemistry. However, from the FVP at $700{ }^{\circ} \mathrm{C} / 4 \times 10^{-2}$ mbar of dimethyl 3-benzoyl-5methyl-1H,3H-pyrrolo[1,2-c] thiazole-6,7-dicarboxylate 2,2- 


\section{SCHEME 10}
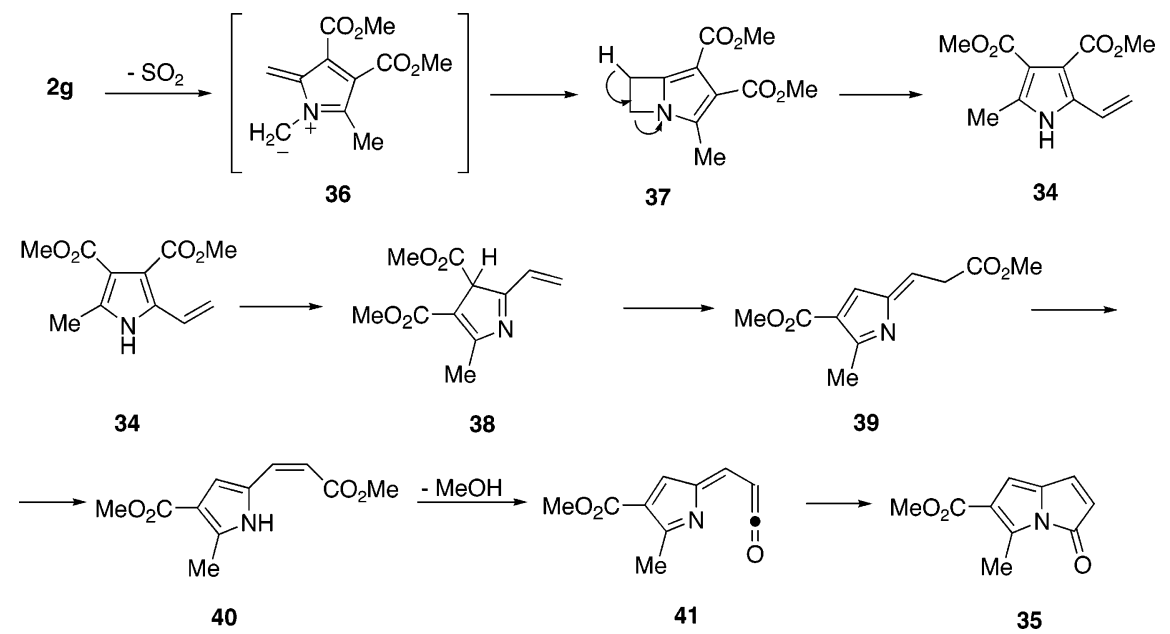

\section{SCHEME 11}

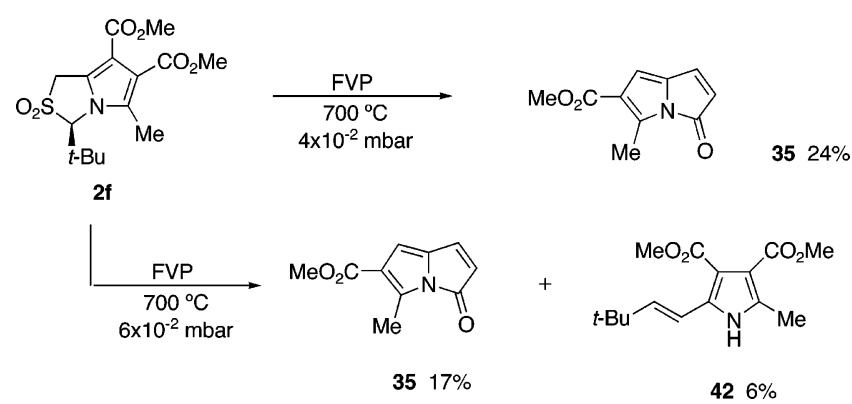

dioxide $\mathbf{2 h}$ no evidence for the formation of the desired product was observed.<smiles>C=C(C(C)=O)c1c(C(C)=O)c(C)n(CC(=O)c2ccccc2)c1C</smiles>

\section{Conclusion}

We described new chemistry of 1-azafulvenium methides, generated by the thermal extrusion of sulfur dioxide from pyrrolo[1,2-c]thiazole-2,2-dioxides. The intramolecular trapping of these transient $8 \pi$ 1,7-dipoles in pericyclic reaction, namely sigmatropic $[1,8] \mathrm{H}$ shifts and 1,7-electrocyclization, leads to the synthesis of $N$ vinylpyrroles and $C$-vinylpyrroles. Under FVP conditions the vinylpyrroles are converted into heterocycles where another ring system is annulated to pyrrole, namely 5-oxo-5H-pyrrolizines and 4-oxo-1,4-dihydro-1-azabenzo[f]azulenes. The synthesis of these heterocycles can also be achieved directly from the flash vacuum pyrolysis of pyrrolo[1,2-c]thiazole-2,2-dioxides. The synthesis of a new 6-oxocyclopenta $[b]$ pyrrole derivative is also reported.

\section{Experimental Section}

General Procedure for the Sealed Tube Reactions. The appropriate $1 H, 3 H$-pyrrolo[1,2-c] thiazole-6,7-dicarboxylate 2,2dioxide $(0.36 \mathrm{mmol})$ was dissolved in sulfolane $(1 \mathrm{~mL})$ in a glass pyrolysis tube which was cooled in liquid nitrogen, evacuated, sealed, and heated (see the Supporting Information). After being cooled to room temperature, the tube was opened and the reaction mixture diluted with dichloromethane and washed with water. The mixture was purified by flash chromatography [ethyl acetate-hexane (1:2) then ethyl acetate-hexane (1:1)].

Dimethyl 2,5-Dimethyl-1-vinyl-1H-pyrrole-3,4-dicarboxylate 3a. Compound 3a was isolated as a white solid (61\%): $\mathrm{mp} 67.5-68.2{ }^{\circ} \mathrm{C}^{9}$ (from diethyl ether-hexane); ${ }^{1} \mathrm{H}$ NMR $2.37(6 \mathrm{H}, \mathrm{s}), 3.81(6 \mathrm{H}, \mathrm{s}), 5.27(1 \mathrm{H}, \mathrm{dd}, J=0.7$ and 15.7 $\mathrm{Hz}), 5.44(1 \mathrm{H}, \mathrm{dd}, J=0.7$ and $8.5 \mathrm{~Hz}), 6.60(1 \mathrm{H}, \mathrm{dd}, J=8.5$ and $15.7 \mathrm{~Hz}$ ); MS (EI) $\mathrm{m} / z 237\left(\mathrm{M}^{+}, 30\right), 205$ (87), 147 (41), 119 (100), 77 (28), 68 (40), and 42 (53).

Dimethyl 2,5-Dimethyl-1-styryl-1H-pyrrole-3,4-dicarboxylate 3b. Compound $\mathbf{3 b}$ was isolated as a white solid (43\%): $\mathrm{mp} 149.6-151.0^{\circ} \mathrm{C}$ (from diethyl ether); IR (KBr) 1225 , 1443,1548 , and $1694 \mathrm{~cm}^{-1} ;{ }^{1} \mathrm{H}$ NMR $2.41(6 \mathrm{H}, \mathrm{s}), 3.82(6 \mathrm{H}, \mathrm{s})$, 6.61 ( $1 \mathrm{H}, \mathrm{dd}, J=14.4 \mathrm{~Hz}$ ), $6.97(1 \mathrm{H}, \mathrm{dd}, J=14.4 \mathrm{~Hz}), 7.35-$ $7.47(5 \mathrm{H}, \mathrm{m}, \mathrm{Ar}-\mathrm{H}) ;{ }^{13} \mathrm{C} \mathrm{NMR} 12.1,51.5,112.9,122.1,126.6$, $128.8,128.9,131.5,133.8,133.9,165.9$; HRMS (CI) $\mathrm{m} / z$ $313.1315\left(\mathrm{C}_{18} \mathrm{H}_{19} \mathrm{NO}_{4}\left[\mathrm{MH}^{+}\right], 313.1314\right)$.

Dimethyl 2,5-Dimethyl-1-(2-methylpropenyl)-1H-pyrrole-3,4-dicarboxylate 13a. Compound 13a was isolated as a solid (36\%): $\mathrm{mp} 54.5-55.8^{\circ} \mathrm{C}$ (from diethyl ether-hexane); IR (KBr) 1091, 1182, 1219, 1443, 1694, and $1715 \mathrm{~cm}^{-1} ;{ }^{1} \mathrm{H}$ NMR $1.47(3 \mathrm{H}, \mathrm{d}, J=1.3 \mathrm{~Hz}), 1.91(3 \mathrm{H}, \mathrm{d}, J=1.4 \mathrm{~Hz}), 2.23$ $(6 \mathrm{H}, \mathrm{s}), 3.81(6 \mathrm{H}, \mathrm{s}), 6.03-6.04(1 \mathrm{H}, \mathrm{m}) ;{ }^{13} \mathrm{C} \mathrm{NMR} 11.4,17.5$, 21.8, 51.3, 111.7, 118.0, 134.3, 140.7, 166.1; MS (EI) $\mathrm{m} / z 265$ $\left(\mathrm{M}^{+}, 28\right), 234$ (39), 218 (100), and 147 (18); HRMS (CI) $\mathrm{m} / \mathrm{z}$ $265.1319\left(\mathrm{C}_{14} \mathrm{H}_{19} \mathrm{NO}_{4}\left[\mathrm{M}^{+}\right], 265.1314\right)$.

Dimethyl 2-Methyl-1-vinyl-1H-pyrrole-3,4-dicarboxylate 13b. Compound 13b was isolated as an oil (8\%): IR (film) $1208,1284,1444$, and $1706 \mathrm{~cm}^{-1} ;{ }^{1} \mathrm{H}$ NMR $2.42(3 \mathrm{H}, \mathrm{s}), 3.81$ $(3 \mathrm{H}, \mathrm{s}), 3.84(3 \mathrm{H}, \mathrm{s}), 4.99(1 \mathrm{H}, \mathrm{dd}, J=1.7$ and $8.8 \mathrm{~Hz}), 5.32$ $(1 \mathrm{H}, \mathrm{dd}, J=1.7$ and $15.5 \mathrm{~Hz}), 6.84(1 \mathrm{H}, \mathrm{dd}, J=8.8$ and 15.5 $\mathrm{Hz})$, 7.43 (1H, s); ${ }^{13} \mathrm{C}$ NMR 10.7, 51.5, 51.6, 104.2, 106.8, 122.1, $122.5,129.3,134.6,164.1,165.3$; HRMS (CI) $\mathrm{m} / \mathrm{z} 224.0925$ $\left(\mathrm{C}_{11} \mathrm{H}_{14} \mathrm{NO}_{4}\left[\mathrm{MH}^{+}\right], 224.0923\right)$.

Methyl 1,3,6-Trimethyl-5-oxo-5H-pyrrolizine-2-carboxylate 16a and Dimethyl 2,5-Dimethyl-1-propenyl-1Hpyrrole-3,4-dicarboxylate 15a. The purification of the crude product by flash chromatography gave, in order of elution, methyl 1,3,6-trimethyl-5-oxo-5H-pyrrolizine-2-carboxylate 16a as solid with an intense orange color (7\%) and dimethyl 2,5dimethyl-1-propenyl- $1 H$-pyrrole-3,4-dicarboxylate $\mathbf{1 5 a}$ as a mixture of the trans/cis (86:14) stereoisomers, obtained as an oil $(41 \%)$.

Methyl 1,3,6-trimethyl-5-oxo-5 $H$-pyrrolizine-2-carboxylate 16a: $\mathrm{mp} 138.0-140.0{ }^{\circ} \mathrm{C}$ (from diethyl ether); IR ( $\mathrm{KBr}$ ) 1129, 1385, 1695, and $1721 \mathrm{~cm}^{-1}$; ${ }^{1} \mathrm{H}$ NMR 1.88 (3H, d, $J=$ $1.6 \mathrm{~Hz}), 2.13(3 \mathrm{H}, \mathrm{s}), 2.63(3 \mathrm{H}, \mathrm{s}), 3.79(3 \mathrm{H}, \mathrm{s}), 6.83(1 \mathrm{H}, \mathrm{d}, J$ $=1.6 \mathrm{~Hz}) ;{ }^{13} \mathrm{C}$ NMR 10.8, 11.7, 12.1, 50.8, 121.7, 128.6, 130.1,

(9) Compound previously described in ref 1 as a yellowish oil. 


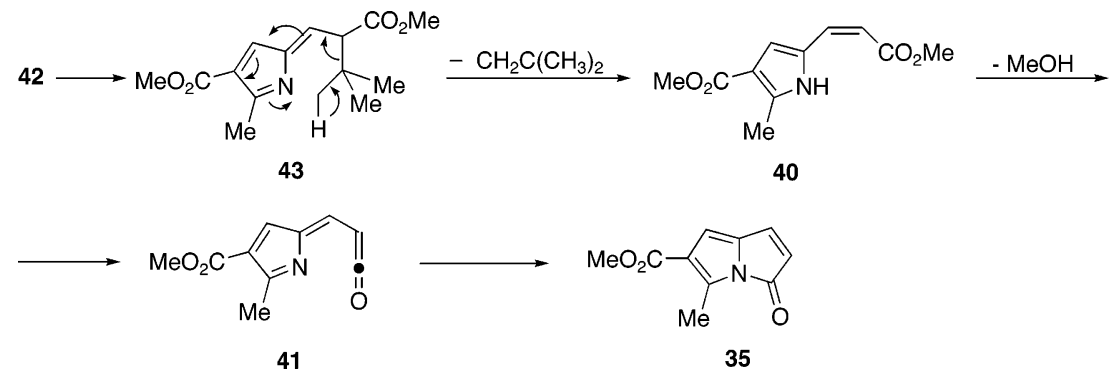

130.6, 131.6, 141.6, 165.4, 167.5; MS (EI) $\mathrm{m} / z 219\left(\mathrm{M}^{+}, 100\right)$, 204 (28), 188 (48), 159 (37), and 130 (11); HRMS (CI) $\mathrm{m} / z$ $219.0892\left(\mathrm{C}_{12} \mathrm{H}_{13} \mathrm{NO}_{3}\left[\mathrm{M}^{+}\right], 219.0895\right)$.

Dimethyl 2,5-dimethyl-1-propenyl-1H-pyrrole-3,4-dicarboxylate 15a: IR (film) 1175, 1217, 1279, 1443, and 1706 $\mathrm{cm}^{-1} ;{ }^{1} \mathrm{H}$ NMR (trans-isomer) $1.89(3 \mathrm{H}, \mathrm{dd}, J=1.7$ and 6.8 $\mathrm{Hz}), 2.31(6 \mathrm{H}, \mathrm{s}), 3.80(6 \mathrm{H}, \mathrm{s}), 5.77(1 \mathrm{H}$, approx sext, $J=6.9$ and $13.8 \mathrm{~Hz}), 6.23-6.27(1 \mathrm{H}, \mathrm{m})$; (cis-isomer) $1.51(3 \mathrm{H}, \mathrm{dd}, J$ $=1.8$ and $6.9 \mathrm{~Hz}), 2.26(6 \mathrm{H}, \mathrm{s}), 3.81(6 \mathrm{H}, \mathrm{s}), 5.97-6.06(1 \mathrm{H}$, $\mathrm{m}), 6.30-6.31(1 \mathrm{H}, \mathrm{m})$; MS (EI) (trans-isomer) $\mathrm{m} / z 251\left(\mathrm{M}^{+}\right.$, 27), 219 (30), 204 (100), 190 (8), 146 (11), and 133 (10); (EI) (cis-isomer) $\mathrm{m} / z 251\left(\mathrm{M}^{+}, 28\right), 219$ (49), 204 (100), 190 (9), 146 (13), and 133 (16); HRMS (CI) $m / z 252.1230\left(\mathrm{C}_{13} \mathrm{H}_{18} \mathrm{NO}_{4}\left[\mathrm{MH}^{+}\right]\right.$, 252.1236)

Dimethyl 2-Methyl-5-phenyl-1-vinyl-1H-pyrrole-3,4-dicarboxylate $\mathbf{1 5 b}$. Compound $\mathbf{1 5 b}$ was isolated as a solid (45\%): $\mathrm{mp} 97.5-98.5{ }^{\circ} \mathrm{C}$ (from diethyl ether); IR (KBr) 1202 , 1233, 1439, 1705, and $1722 \mathrm{~cm}^{-1} ;{ }^{1} \mathrm{H}$ NMR $2.54(3 \mathrm{H}, \mathrm{s}), 3.67$ $(3 \mathrm{H}, \mathrm{s}), 3.83(3 \mathrm{H}, \mathrm{s}), 5.03(1 \mathrm{H}, \mathrm{dd}, J=0.9$ and $15.8 \mathrm{~Hz}), 5.18$ $(1 \mathrm{H}, \mathrm{dd}, J=0.9$ and $8.7 \mathrm{~Hz}), 6.48(1 \mathrm{H}, \mathrm{dd}, J=8.7$ and 15.8 $\mathrm{Hz}), 7.36(5 \mathrm{H}, \mathrm{bs}) ;{ }^{13} \mathrm{C}$ NMR $12.4,51.5,51.8,112.7,113.6$, 115.7, 123.6, 128.0. 128.4, 128.8, 130.2, 130.6, 135.1, 165.2, 166.1; MS (EI) m/z 299 ( $\left.\mathrm{M}^{+}, 89\right), 267$ (100), 207 (75), 180 (44), 117 (22), and 104 (19). Anal. Calcd for $\mathrm{C}_{17} \mathrm{H}_{17} \mathrm{NO}_{4}$ : C, 68.21; H, 5.72; N, 4.68. Found: C, 68.28; H, 6.07; N, 4.37.

Dimethyl 2-Methyl-5-styryl-1H-pyrrole-3,4-dicarboxylate 4a. Compound 4a was isolated as a solid (54\%): $\mathrm{mp} 151.9-$ $153.6^{\circ} \mathrm{C}$ (from diethyl ether); IR (KBr) $1218,1259,1448,1672$, 1717, and $3268 \mathrm{~cm}^{-1} ;{ }^{1} \mathrm{H}$ NMR $2.40(3 \mathrm{H}, \mathrm{s}), 3.80(3 \mathrm{H}, \mathrm{s}), 3.85$ $(3 \mathrm{H}, \mathrm{s}), 6.77(1 \mathrm{H}, \mathrm{d}, J=16.8 \mathrm{~Hz}), 7.32(1 \mathrm{H}, \mathrm{d}, J=16.8 \mathrm{~Hz})$, 7.19-7.38 (5H, m); ${ }^{13} \mathrm{C}$ NMR 12.6, 51.5, 51.8, 113.0, 114.2, $116.3,126.4,127.8,127.9,128.6,132.3,135.7,136.5,165.7$, 165.9; MS (EI) m/z $299\left(\mathrm{M}^{+}, 100\right), 267$ (53), 236 (39), 209 (25), and 180 (51). Anal. Calcd for $\mathrm{C}_{17} \mathrm{H}_{17} \mathrm{NO}_{4}$ : C, 68.22; H, 5.72; N, 4.68. Found: C, 68.60; H, 6.07; N, 4.79.

Dimethyl 2-Phenyl-5-styryl-1H-pyrrole-3,4-dicarboxylate $4 \mathbf{b}$. Compound $\mathbf{4 b}$ was isolated as a white solid $(80 \%)$ : $\mathrm{mp}$ 198.2-199. ${ }^{\circ} \mathrm{C}$ (from diethyl ether); IR (KBr) 1220, 1260, 1445,1693 , and $3239 \mathrm{~cm}^{-1} ;{ }_{1}^{1} \mathrm{H}$ NMR $3.81(3 \mathrm{H}, \mathrm{s}), 3.87(3 \mathrm{H}, \mathrm{s})$, $6.87(1 \mathrm{H}, \mathrm{d}, J=16.9 \mathrm{~Hz}), 7.28-7.55(10 \mathrm{H}, \mathrm{m}), 7.64(1 \mathrm{H}, \mathrm{d}, J$ $=16.9 \mathrm{~Hz}) ;{ }^{13} \mathrm{C}$ NMR 51.6, 52.2, 113.8, 115.3, 116.6, 126.6, $127.4,128.1,128.5,128.7,128.7,129.0,130.4,133.4,134.4$, 136.3, 164.7, 166.8; MS (EI) $\mathrm{m} / z 361\left(\mathbf{M}^{+}, 100\right), 298$ (47), 270 (35), 254 (19), 120 (23), and 96 (23); HRMS (CI) $\mathrm{m} / z 361.1302$ $\left(\mathrm{C}_{22} \mathrm{H}_{19} \mathrm{NO}_{4}\left[\mathrm{M}^{+}\right], 361.1314\right)$.

Dimethyl 2-Styryl-1H-pyrrole-3,4-dicarboxylate 4c. $\mathrm{Pu}$ rification by flash chromatography [ethyl acetate-hexane (1: $2)$, ethyl acetate-hexane (1:1), then ethyl acetate-hexane (2: 1)] gave 4c as a solid (24\%): $\mathrm{mp} 162.0-164.1^{\circ} \mathrm{C}$ (from diethyl ether); IR (KBr) 1065, 1288, 1445, 1704, 1728, and $3292 \mathrm{~cm}^{-1}$; ${ }^{1} \mathrm{H}$ NMR 3.83 (3H, s), 3.91 (3H, s), 6.81 (1H, d, $\left.J=16.8\right), 7.28-$ $7.38(4 \mathrm{H}, \mathrm{m}), 7.44-7.49(2 \mathrm{H}, \mathrm{m}), 7.46(1 \mathrm{H}, \mathrm{d}, J=16.8), 8.87$ $(1 \mathrm{H}, \mathrm{bs}) ;{ }^{13} \mathrm{C}$ NMR 51.6, 51.9, 113.5, 116.5, 116.6, 125.2, 126.5, 128.1, 128.7, 129.0, 135.0, 136.3, 164.5, 165.6; MS (EI) $\mathrm{m} / z 285$ ( $\left.\mathrm{M}^{+}, 100\right), 252$ (28), 222 (49), 194 (35), 167 (25), and 139 (19); HRMS (CI) $m / z 285.0995\left(\mathrm{C}_{16} \mathrm{H}_{15} \mathrm{NO}_{4}\left[\mathrm{M}^{+}\right], 285.1001\right)$.

General Procedure for the Flash Vacuum Pyrolysis. Pyrolysis of the appropriate $1 H, 3 H$-pyrrolo[1,2-c] thiazole 2,2dioxide or vinyl- $1 H$-pyrrole $(0.8 \mathrm{mmol})$ at $700{ }^{\circ} \mathrm{C} / 2 \times 10^{-2}-8$ $\times 10^{-2}$ mbar onto a surface cooled at $-196{ }^{\circ} \mathrm{C}$ over a period of $1.5-5 \mathrm{~h}$ gave a yellowish pyrolysate (or red pyrolysate where indicated) [The rate of volatilization of the starting material was controlled by the use of a Kugelrohr oven which heated the sample at $100-250^{\circ} \mathrm{C}$ ] (see the Supporting Information). After being cooled to room temperature, the pyrolysate was removed from the coldfinger with dichloromethane and the solvent was removed in vacuo.

Methyl 1,3-Dimethyl-5-oxo-5H-pyrrolizine-2-carboxylate $\mathbf{5} \mathbf{a}^{\mathbf{3}}$ from $2 \mathbf{a}$. The crude product was purified by flash chromatography [ethyl acetate-hexane (1:2), then ethyl acetate-hexane (1:1)] to give $\mathbf{5 a}$ as a solid with an intense orange color (46\%): $\mathrm{mp} 116.0-118.0{ }^{\circ} \mathrm{C}$ (from diethyl ether-hexane); IR (KBr) 1614, 1695 and $1729 \mathrm{~cm}^{-1} ;{ }^{1} \mathrm{H}$ NMR 2.11 (3H, s, H-8), $2.57(3 \mathrm{H}, \mathrm{s}, \mathrm{H}-11), 3.73(3 \mathrm{H}, \mathrm{s}, \mathrm{H}-10), 5.58(1 \mathrm{H}, \mathrm{d}, J=6.0 \mathrm{~Hz}$, $\mathrm{H}-6), 7.12(1 \mathrm{H}, \mathrm{d}, J=6 \mathrm{~Hz}, \mathrm{H}-7) ;{ }^{13} \mathrm{C}$ NMR (off-resonance decoupling) 10.9 (q, $J=129.2 \mathrm{~Hz}, \mathrm{C}-8), 11.2(\mathrm{q}, J=130.7 \mathrm{~Hz}$, C-11), 49.9 (q, $J=147.4 \mathrm{~Hz}, \mathrm{C}-10$ ), 117.1 (s, C-2), 119.0 (d, $J$ $=181.9 \mathrm{~Hz}, \mathrm{C}-6), 123.7$ (s, C-1), $131.4(\mathrm{~s}, \mathrm{C}-7 \mathrm{a}), 135.9$ (d, $J=$ $174.7 \mathrm{~Hz}, \mathrm{C}-7$ ), 141.3 (s, C-3), 164.3 (s, C-9), 165.6 (s, C-5); MS (EI) $\mathrm{m} / z 205\left(\mathrm{M}^{+}, 100\right), 190(24), 174(69), 162(16), 145$ (45), and 117 (16); HRMS (CI) $m / z 205.0746\left(\mathrm{C}_{11} \mathrm{H}_{11} \mathrm{NO}_{3}\left[\mathrm{M}^{+}\right]\right.$, 205.0739).

Methyl 1,3-Dimethyl-5-oxo-5H-pyrrolizine-2-carboxylate 5 a from 3a. The crude product was purified by flash chromatography [ethyl acetate-hexane (1:2), then ethyl acetate-hexane (1:1)] to give $\mathbf{5 a}$ in $79 \%$ yield. The product was identified by comparison with the specimen previously prepared.

Methyl 1,3-Dimethyl-5-oxo-6-phenyl-5H-pyrrolizine-2carboxylate $5 \mathbf{b}$ from $2 c$. The crude product (red pyrolysate) was purified by flash chromatography [ethyl acetate-hexane (1:2)] to give $\mathbf{5 b}$ as a solid with an intense dark red color (44\%): $\mathrm{mp} 126.8-127.9{ }^{\circ} \mathrm{C}$ (washed with diethyl ether); IR (KBr) 1132,1688 , and $1730 \mathrm{~cm}^{-1} ;{ }^{1} \mathrm{H}$ NMR $2.22(3 \mathrm{H}, \mathrm{s}), 2.70$ $(3 \mathrm{H}, \mathrm{s}), 3.81(3 \mathrm{H}, \mathrm{s}), 7.27-7.41(3 \mathrm{H}, \mathrm{m}, \mathrm{Ar}-\mathrm{H}), 7.32(1 \mathrm{H}, \mathrm{s})$, 7.74-7.78 (2H, m); ${ }^{13} \mathrm{C}$ NMR 12.0, 12.3, 50.9, 118.3, 124.1, $126.2,128.1,128.6,128.7,130.8,131.2,131.3,142.3,165.2$, 165.6; MS (EI) $\mathrm{m} / z 281\left(\mathrm{M}^{+}, 100 \%\right), 266$ (12), 258 (18), 221 (26), and $152(10)$; HRMS (CI) $m / z 282.1126\left(\mathrm{C}_{17} \mathrm{H}_{16} \mathrm{NO}_{3}\left[\mathrm{MH}^{+}\right]\right.$, 282.1130)

Methyl 1,3-Dimethyl-5-oxo-6-phenyl-5H-pyrrolizine-2carboxylate $5 \mathbf{b}$ from $3 \mathbf{b}$. The crude product (red pyrolysate) was purified by preparative thin-layer chromatography [ethylacetate-hexane (1:2)] to give $\mathbf{5 b}$ in $56 \%$ yield. The product was identified by comparison with the specimen previously prepared.

Dimethyl 2,5-Dimethyl-1-(2-methylpropenyl)-1H-pyrrole-3,4-dicarboxylate 13a and Methyl 5-Isopropenyl-2methyl-6-oxo-1,4,5,6-tetrahydrocyclopenta[b]pyrrole-3carboxylate 14 from $2 e$. The crude product was purified by flash chromatography [ethyl acetate-hexane (1:2), then ethyl acetate-hexane (1:1)] to give 13a (13\%) and $\mathbf{1 4}(7 \%)$ both as solids. The pyrrole 13a was identified by comparison with the specimen previously prepared.

Methyl 5-isopropenyl-2-methyl-6-oxo-1,4,5,6-tetrahydrocyclopenta[b]pyrrole-3-carboxylate 14: $\mathrm{mp}$ 156.4$158.2^{\circ} \mathrm{C}$ (from diethyl ether); IR (KBr) 1086, 1119, 1277, 1460, 1661, 1717, and $3163 \mathrm{~cm}^{-1}$; ${ }^{1} \mathrm{H}$ NMR $1.68-1.69$ (3H, m), 2.66 
(3H, s), $2.89(1 \mathrm{H}, \mathrm{dd}, J=2.3$ and $18.1 \mathrm{~Hz}), 3.26(1 \mathrm{H}, \mathrm{dd}, J=$ 6.6 and $18.1 \mathrm{~Hz}), 3.61(1 \mathrm{H}, \mathrm{dd}, J=2.3$ and $6.6 \mathrm{~Hz}), 3.83(3 \mathrm{H}$, s), 4.94-4.97 (2H, m), $10.85(1 \mathrm{H}, \mathrm{s}) ;{ }^{13} \mathrm{C}$ NMR $14.3,19,2,28.6$, 51.0, 59.8, 110.3, 114.0, 131.9, 142.9, 150.8, 155.7, 164.9, 191.7; MS (EI) m/z $233\left(\mathrm{M}^{+}, 100\right), 218$ (46), 190 (26), 174 (45), 146 (22), 131 (14), and 77 (8); HRMS (CI) $\mathrm{m} / z 233.1055\left(\mathrm{C}_{13} \mathrm{H}_{15^{-}}\right.$ $\left.\mathrm{NO}_{3}\left[\mathrm{M}^{+}\right], 233.1052\right)$.

Methyl 1,3,6-Trimethyl-5-oxo-5H-pyrrolizine-2-carboxylate 16a from 2d. The crude product was purified by flash chromatography [ethyl acetate-hexane (1:2)] to give 16a as a solid with an intense orange color $(39 \%)$. The product was identified by comparison with the specimen previously prepared.

Methyl 1,3,6-Trimethyl-5-oxo-5H-pyrrolizine-2-carboxylate 16a from 15a. Compound 16a was isolated as a solid with an intense orange color $(72 \%)$. The product was identified by comparison with the specimen previously prepared.

Methyl 3-Methyl-5-oxo-1-phenyl-5H-pyrrolizine-2-carboxylate 16c and Methyl 1-Methyl-5-oxo-3-phenyl-5Hpyrrolizine-2-carboxylate $16 \mathrm{~b}$ from $2 \mathrm{i}$. The crude product was purified by preparative thin-layer chromatography [ethy] acetate-hexane (1:3)] to give, in order of elution, 16c (13\%), $\mathbf{1 6 b}(8 \%)$, both as solids with an intense orange color, and $\mathbf{1 5 b}$ $(3 \%)$.

Methyl 3-methyl-5-oxo-1-phenyl-5H-pyrrolizine-2-carboxylate 16c: $\mathrm{mp} 128.7-130.5{ }^{\circ} \mathrm{C}$ (from diethyl ether); IR (KBr) 1079, 1154, 1195, 1387, 1699, and $1731 \mathrm{~cm}^{-1} ;{ }^{1} \mathrm{H}$ NMR $2.71(3 \mathrm{H}, \mathrm{s}), 3.69(3 \mathrm{H}, \mathrm{s}), 5.78(1 \mathrm{H}, \mathrm{d}, J=5.8 \mathrm{~Hz}), 7.15(1 \mathrm{H}, \mathrm{d}$, $J=5.8 \mathrm{~Hz}), 7.34-7.38(5 \mathrm{H}, \mathrm{m}) ;{ }^{13} \mathrm{C} \mathrm{NMR} 12.2,51.0,121.5$, $127.9,128.0,128.1,129.2,132.4,132.5,137.9,142.0,164.7$, 166.5; MS (EI) $\mathrm{m} / z 267$ ( $\left.\mathrm{M}^{+}, 100\right), 236$ (46), 207 (16), 179 (23), 152 (14), and 76 (7); HRMS (CI) $m / z 267.0902\left(\mathrm{C}_{16} \mathrm{H}_{13} \mathrm{NO}_{3}\left[\mathrm{M}^{+}\right]\right.$, 267.0895).

Methyl 1-methyl-5-oxo-3-phenyl-5H-pyrrolizine-2-carboxylate 16b: $\mathrm{mp} 128.4-129.2{ }^{\circ} \mathrm{C}$ (from diethyl ether); IR (KBr) 1076, 1139, 1195, 1370, 1705, and $1742 \mathrm{~cm}^{-1} ;{ }^{1} \mathrm{H}$ NMR $2.24(3 \mathrm{H}, \mathrm{s}), 3.62(3 \mathrm{H}, \mathrm{s}), 5.68(1 \mathrm{H}, \mathrm{d}, J=5.9 \mathrm{~Hz}), 7.24(1 \mathrm{H}, \mathrm{d}$, $J=5.9 \mathrm{~Hz}), 7.40-7.44(3 \mathrm{H}, \mathrm{m}), 7.52-7.55(2 \mathrm{H}, \mathrm{m}) ;{ }^{13} \mathrm{C} \mathrm{NMR}$ 11.7, 50.9, 118.9, 121.1, 124.3, 127.6, 128.4, 129.7, 134.0, 136.7, 141.6, 164.6, 165.6; MS (EI) $\mathrm{m} / z 267\left(\mathrm{M}^{+}, 100\right), 236$ (46), 208 (10), 180 (19), and 77 (10). Anal. Calcd for $\mathrm{C}_{16} \mathrm{H}_{15} \mathrm{NO}_{3}$ : C, 71.90; H, 4.90; N, 5.24. Found: C, 71.69; H, 5.13; N, 5.26.

Methyl 3-Methyl-5-oxo-1-phenyl-5H-pyrrolizine-2-carboxylate 16c and Methyl 1-Methyl-5-oxo-3-phenyl-5Hpyrrolizine-2-carboxylate $16 \mathrm{~b}$ from $15 \mathrm{~b}$. The crude product was purified by preparative thin-layer chromatography [ethyl acetate-hexane (1:3)] to give $\mathbf{1 6 c}(6 \%)$ and $\mathbf{1 6 b}(10 \%)$, both as solids with an intense orange color. The products were identified by comparison with the specimens previously prepared.

Methyl 2-Methyl-4-oxo-1,4-dihydro-1-azabenzo[f]azulene-3-carboxylate 6 a from $2 \mathbf{b}$. The crude product was purified by flash chromatography [ethyl acetate-hexane (1: 2 ) and then ethyl acetate-hexane (1:1)] to give $\mathbf{6 a}$ as a yellow solid (22\%): $\mathrm{mp} 261.0-263.0^{\circ} \mathrm{C}$ (from diethyl ether-hexane); IR (KBr) 1492, 1545, 1697, $3238 \mathrm{~cm}^{-1} ;{ }^{1} \mathrm{H}$ NMR $2.77(3 \mathrm{H}, \mathrm{s})$, $3.95(3 \mathrm{H}, \mathrm{s}), 7.36(1 \mathrm{H}, \mathrm{d}, J=12.0 \mathrm{~Hz}), 7.67-7.75(1 \mathrm{H}, \mathrm{m})$, $7.77-7.80(1 \mathrm{H}, \mathrm{m}), 7.84(1 \mathrm{H}, \mathrm{dd}, J=1.4$ and $7.8 \mathrm{~Hz}), 8.27$ $(1 \mathrm{H}, \mathrm{d}, J=12.0 \mathrm{~Hz}), 9.96(1 \mathrm{H}, \mathrm{dd}, J=1.5$ and $8.0 \mathrm{~Hz}), 10.64$ (1H, bs); MS (EI) m/z $267\left(\mathrm{M}^{+}, 100\right), 252$ (11), 236 (64), 178 (12), 152 (37) and 76 (16); HRMS (CI) $m / z 267.0903\left(\mathrm{C}_{16} \mathrm{H}_{13^{-}}\right.$ $\left.\mathrm{NO}_{3}\left[\mathrm{M}^{+}\right], 267.0895\right)$.

Methyl 2-Methyl-4-oxo-1,4-dihydro-1-azabenzo[f]azulene-3-carboxylate 6a from 4a. The crude product was purified by preparative thin-layer chromatography [ethyl acetate-hexane (1:2)] to give $\mathbf{6 a}$ as a yellow solid (31\%). The product was identified by comparison with the specimen previously prepared.

Methyl 4-Oxo-2-phenyl-1,4-dihydro-1-azabenzo[f]azulene-3-carboxylate $\mathbf{6 b}$ from $2 \mathbf{j}$. The crude product was purified by flash chromatography [ethyl-acetate-hexane (1: $3)$ ] to give $\mathbf{6 b}$ as a yellow oil (2\%): IR (film) 1443, 1559, 1653,
1702 , and $3224 \mathrm{~cm}^{-1}$; ${ }^{1} \mathrm{H}$ NMR $3.71(3 \mathrm{H}, \mathrm{s}), 6.93(1 \mathrm{H}, \mathrm{d}, J=$ $2.9 \mathrm{~Hz}), 7.32-7.84(6 \mathrm{H}, \mathrm{m}), 7.72(1 \mathrm{H}, \mathrm{d}, J=9.3 \mathrm{~Hz}), 8,40(1 \mathrm{H}$, $\mathrm{d}, J=9.3 \mathrm{~Hz}), 8.97-9.01(2 \mathrm{H}, \mathrm{m}), 9.44(1 \mathrm{H}, \mathrm{bs}) ; \mathrm{MS}(\mathrm{EI}) \mathrm{m} / \mathrm{z}$ $329\left(\mathrm{M}^{+}, 100\right), 301$ (26), 270 (84), 241 (52) and 120 (27); HRMS (CI) $\mathrm{m} / z 330.1139\left(\mathrm{C}_{21} \mathrm{H}_{16} \mathrm{NO}_{3}\left[\mathrm{MH}^{+}\right], 330.1130\right)$.

Methyl 4-Oxo-1,4-dihydro-1-azabenzo[f]azulene-2-carboxylate 27 and Methyl 4-Oxo-1,4-dihydro-1-azabenzo[f]azulene-3-carboxylate 6c from 21 . The crude product was purified by flash chromatography [ethyl -acetate-hexane (1: 3 ), ethyl acetate-hexane (1:2) and then ethyl acetate-hexane (1:1)] to give, in order of elution, 27 (11\%) and 6c (10\%), both as orange solids.

Methyl 4-oxo-1,4-dihydro-1-azabenzo[f]azulene-2-carboxylate 27: $\mathrm{mp} 141.6-143.5^{\circ} \mathrm{C}$ (from diethyl ether); IR ( $\mathrm{KBr}$ ) 1083, 1236, 1442, 1672, and $1711 \mathrm{~cm}^{-1} ;{ }^{1} \mathrm{H}$ NMR $3.96(3 \mathrm{H}, \mathrm{s})$, $7.53-7.58(1 \mathrm{H}, \mathrm{m}), 7.72(1 \mathrm{H}, \mathrm{dd}, J=1.6$ and $8.7 \mathrm{~Hz}), 7.74$ $(1 \mathrm{H}, \mathrm{d}, J=9.1 \mathrm{~Hz}), 7.81(1 \mathrm{H}, \mathrm{dd}, J=1.5$ and $7.9 \mathrm{~Hz}), 8.04$ $(1 \mathrm{H}, \mathrm{s}), 8.35(1 \mathrm{H}, \mathrm{d}, J=9.1 \mathrm{~Hz}), 9.40(1 \mathrm{H}, \mathrm{d}, J=8.7 \mathrm{~Hz}), 9.76$ (1H, bs); ${ }^{13} \mathrm{C}$ NMR 51.5, 108.9, 117.4, 121.0, 125.0, 126.0, 128.5, $129.2,129.7,130.0,134.3,134.8,141.4,163.9,176.8$; HRMS (CI) $\mathrm{m} / z 254.0817\left(\mathrm{C}_{15} \mathrm{H}_{12} \mathrm{NO}_{3}\left[\mathrm{MH}^{+}\right], 254.0810\right)$. Anal. Calcd for $\mathrm{C}_{15} \mathrm{H}_{11} \mathrm{NO}_{3}$ : C, 71.14; $\mathrm{H}, 4.38 ; \mathrm{N}, 5.53$. Found: C, 71.40; $\mathrm{H}, 4.84 ; \mathrm{N}, 5.15$.

Methyl 4-oxo-1,4-dihydro-1-azabenzo[f]azulene-3-carboxylate 6c: $\mathrm{mp} 229.0-231.0^{\circ} \mathrm{C}$ (from diethyl ether); $\mathrm{IR}(\mathrm{KBr})$ 1155, 1441, 1575, 1714, and $3343 \mathrm{~cm}^{-1} ;{ }^{1} \mathrm{H}$ NMR $3.92(3 \mathrm{H}, \mathrm{s})$, $7.38(1 \mathrm{H}, \mathrm{d}, J=11.8 \mathrm{~Hz}), 7.53-7.86(3 \mathrm{H}, \mathrm{m}), 8.01(1 \mathrm{H}, \mathrm{d}, J=$ $3.3 \mathrm{~Hz}), 8.29(1 \mathrm{H}, \mathrm{d}, J=11.8 \mathrm{~Hz}), 8.95(1 \mathrm{H}, \mathrm{dd}, J=1.5$ and $8.1 \mathrm{~Hz}) ;{ }^{13} \mathrm{C}$ NMR 51.4, 119.2, 123.8, 127.7, 127.8, 128.4, 128.8, $130.5,131.0,132.4,132.5,134.8,137.0,164.6,176.9$; MS (EI) $\mathrm{m} / \mathrm{z} 253\left(\mathrm{M}^{+}, 100\right), 222$ (53), $207(25), 139$ (18) and 73 (27); HRMS (CI) $\mathrm{m} / z 253.0734\left(\mathrm{C}_{15} \mathrm{H}_{11} \mathrm{NO}_{3}\left[\mathrm{M}^{+}\right], 253.0739\right)$.

Methyl 4-Oxo-1,4-dihydro-1-azabenzo[f]azulene-2-carboxylate 27 and Methyl 4-Oxo-1,4-dihydro-1-azabenzo[f]azulene-3-carboxylate $6 \mathrm{c}$ from $4 c$. The crude product was purified by flash chromatography [ethyl acetate-hexane (1: 3 ) and then ethyl acetate-hexane (1:2)] to give 27 (37\%) and 6c $(14 \%)$, both as orange solids. The products were identified by comparison with the specimens previously prepared.

Methyl 3-Methyl-5-oxo-5H-pyrrolizine-2-carboxylate 35 and Dimethyl 2-Methyl-5-vinyl-1H-pyrrole-3,4-dicarboxylate 34 from $2 \mathrm{~g}$. The crude product was purified by flash chromatography [ethyl acetate-hexane (1:3), ethyl acetatehexane (1:2), and then ethyl acetate-hexane (1:1)] to give $\mathbf{3 5}$ $(8 \%)$ as a solid with an intense orange color and $\mathbf{3 4}(10 \%)$ as a white solid.

Methyl 3-methyl-5-oxo-5H-pyrrolizine-2-carboxylate $\mathbf{3 5}$ was identified by comparison with the specimen previously prepared (see below).

Dimethyl 2-methyl-5-vinyl-1H-pyrrole-3,4-dicarboxylate 34: $\mathrm{mp} 115.9-117.7^{\circ} \mathrm{C}$ (from diethyl ether); IR (KBr) 1100 , 1210, 1295, 1450, 1694, 1709, and $3307 \mathrm{~cm}^{-1} ;{ }^{1} \mathrm{H}$ NMR 2.41 $(3 \mathrm{H}, \mathrm{s}), 3.80(3 \mathrm{H}, \mathrm{s}), 3.83(3 \mathrm{H}, \mathrm{s}), 5.21(1 \mathrm{H}, \mathrm{d}, J=11.5 \mathrm{~Hz})$, $5.43(1 \mathrm{H}, \mathrm{d}, J=18.0 \mathrm{~Hz}), 6.91(1 \mathrm{H}, \mathrm{dd}, J=11.4$ and $18.0 \mathrm{~Hz})$, $8.92(1 \mathrm{H}, \mathrm{bs}) ;{ }^{13} \mathrm{C}$ NMR $12.7,51.4,51.8,112.6,112.7,114.2$, $125.0,131.6,135.2,165.4,165.6$; MS (EI) $223\left(\mathrm{M}^{+}, 43\right), 191$ (100), 162 (19), 133 (36), and 105 (34); HRMS (CI) $\mathrm{m} / \mathrm{z} 223.0843$ $\left(\mathrm{C}_{11} \mathrm{H}_{13} \mathrm{NO}_{4}\left[\mathrm{M}^{+}\right], 223.0845\right)$.

Methyl 3-Methyl-5-oxo-5H-pyrrolizine-2-carboxylate 35 from 2 f. The crude product was purified by flash chromatography [ethyl acetate-hexane (1:3)] to give methyl 3-methyl5-oxo-5H-pyrrolizine-2-carboxylate $\mathbf{3 5}$ as a solid with an intense orange color $(24 \%)$ : $\mathrm{mp} 91.8-93.9{ }^{\circ} \mathrm{C}$ (from hexane); IR $(\mathrm{KBr}) 1179,1199,1702$, and $1734 \mathrm{~cm}^{-1} ;{ }^{1} \mathrm{H}$ NMR $2.68(3 \mathrm{H}$, s), $3.80(3 \mathrm{H}, \mathrm{s}), 5.75(1 \mathrm{H}, \mathrm{d}, J=5.9 \mathrm{~Hz}), 6.38(1 \mathrm{H}, \mathrm{s}), 7.17$ $(1 \mathrm{H}, \mathrm{d}, J=5.9 \mathrm{~Hz}) ;{ }^{13} \mathrm{C}$ NMR $11.6,51.2,111.8,118.4,121.9$, 134.0, 138.2, 141.1, 164.6, 166.6; MS (EI) $\mathrm{m} / z 191\left(\mathrm{M}^{+}, 92\right)$, 176 (34), 160 (100), 132 (24), 104 (9), and 77 (10); HRMS (CI) $\mathrm{m} / z 191.0577\left(\mathrm{C}_{10} \mathrm{H}_{9} \mathrm{NO}_{3}\left[\mathrm{M}^{+}\right], 191.0582\right)$.

Carrying out the pyrolysis of $\mathbf{2 f}$ at $700{ }^{\circ} \mathrm{C} / 6 \times 10^{-2} \mathrm{mbar}$ ,two products are obtained: methyl 3-methyl-5-oxo-5H-pyr- 


\section{JOC Article}

rolizine-2-carboxylate 35 (17\%) and dimethyl 2-(3,3-dimethylbut-1-enyl)-5-methyl-1 $H$-pyrrole-3,4-dicarboxylate 42 (6\%).

Dimethyl 2-(3,3-dimethylbut-1-enyl)-5-methyl-1H-pyrrole3,4-dicarboxylate 42 was obtained as an oil: IR (film) 1097, 1216, 1448, 1707, and $3309 \mathrm{~cm}^{-1}$; ${ }^{1} \mathrm{H}$ NMR 1.08 (9H, s), 2.41 $(3 \mathrm{H}, \mathrm{s}), 3.80(3 \mathrm{H}, \mathrm{s}), 3.83(3 \mathrm{H}, \mathrm{s}), 5.95(1 \mathrm{H}, \mathrm{d}, J=16.6 \mathrm{~Hz})$, 6.59 (1H, d, $J=16.6 \mathrm{~Hz}$ ); MS (EI) $\mathrm{m} / z 279\left(\mathrm{M}^{+}, 61\right), 248$ (31), 232 (100), 222 (90), 200 (84), and 160 (30); HRMS (CI) $\mathrm{m} / \mathrm{z}$ $279.1475\left(\mathrm{C}_{15} \mathrm{H}_{21} \mathrm{NO}_{4}\left[\mathrm{M}^{+}\right], 279.1471\right)$.

X-ray crystal data for methyl 5-isopropenyl-2-methyl6-oxo-1,4,5,6-tetrahydrocyclopenta[b]pyrrole-3-carboxylate 14: $\mathrm{C}_{13} \mathrm{H}_{15} \mathrm{NO}_{3}, M_{\mathrm{r}}=233.26 \mathrm{amu}$, triclinic, space group $P \overline{1}$ with unit cell $a=5.160(2) \AA, b=10.5619(7) \AA, c=11.939$ (2) $\AA, a=108.097(8)^{\circ}, b=99.00(3)^{\circ}, \gamma=94.537(17)^{\circ}$, and $V=$ $605.2(3) \AA^{3}$. It contains two molecules/unit cell. $D_{\text {calc }}=1.280$ $\mathrm{g} \mathrm{cm}^{-3}, Z=2, T=293 \mathrm{~K}, m(\mathrm{Cu} \mathrm{K} \alpha)=0.748 \mathrm{~mm}^{-1} . R(I>$ $2 \sigma(I))=0.0445$ and $R_{\mathrm{w}}=0.1188$ for 2406 independent reflections. The hydrogen atoms were placed at calculated positions and refined as riding on their parent atoms.
Pinho e Melo et al

Acknowledgment. We thank Chymiotechnon and Fundação para a Ciência e a Tecnologia (POCTI/QUI/ 55584/2004 and SFRH/BD/9123/2002) for financial support.

Supporting Information Available: Experimental procedures and characterization data for the synthesis of $N$-formyl1,3-thiazolidines, $1 H, 3 H$-pyrrolo[1,2-c]thiazoles, and $1 H, 3 H$ pyrrolo[1,2-c] thiazole-2,2-dioxides. ${ }^{1} \mathrm{H}$ NMR and ${ }^{13} \mathrm{C}$ NMR spectra for selected compounds. Crystallographic data for methyl 5-isopropenyl-2-methyl-6-oxo-1,4,5,6-tetrahydrocyclopenta[b]pyrrole-3-carboxylate 14 . Reaction conditions for the sealed tube reactions and for the flash vacuum pyrolysis. This material is available free of charge via the Internet at http://pubs.acs.org.

JO050480I 